\title{
ANALISIS GAYA KEPEMIMPINAN DI PDAM KOTA PROBOLINGGO (MODEL HERSEY DAN BLANCHARD)
}

\author{
Tony Dwi Faizal \\ Department of Management FEB UMM \\ E-mail: tonydwif2393@gmail.com
}

\begin{abstract}
This study aims to find out and explain the leadership style analysis in PDAM Kota Probolinggo. The data used in this study are primary data and secondary data. The population in this study is that all permanent employees as much as fifty nine are located in the Administration and Finance Section, in the Customer Relations Section and in the Engineering Section of the City of Probolinggo PDAM with data analysis techniques using a range of scales. Based on the results of the research and discussion that has been done then it can be concluded as follows: First the results of the analysis of the maturity of the subordinates in the Administration and Finance Section is in the very high category, in the Customer Relations section is in the very high category and in the Engineering Section is in the very high category. Both the results of the analysis of the task behavior and relationship behavior in the Administration and Finance Section are in the very high category, in the Customer Relations section is in the very high category and in the Engineering Section is in the very high category. The three results of the analysis of the leadership style applied to PDAM Probolinggo City in the Financial Administration Section are telling, in the Customer Relations Section, namely telling, in the Engineering Section, namely telling. The four leadership styles that are applied according to the Hersey and Blanchard models in the Administration and Finance Section are delegating, in the Customer Relations section, namely delegating, in the Engineering Section, which is participating.
\end{abstract}

Keywords: maturity liege, task behavior, behavior relationships

\section{PENDAHULUAN}

Manusia merupakan sumber daya yang paling penting untuk mencapai keberhasilan visi dan misi perusahaan dan juga proses menajemen dari perencanaan, pengorganisasian, pengarahan dan pengendalian. Permasalahan yang dialami oleh organisasi dan manajemen perusahaan dengan sumber daya manusia diantaranya: konflik yang bersifat negatif antara pimpinan dan karyawannya, tuntutan serikat pekerja terhadap perusahaan, rasa tidak adil pada karyawan kerja yang monoton, tidak adanya kesempatan pengembangan karir, Keenam pihak manajemen perusahaan yang tidak aktif ke karyawannya, Ketujuh sumber daya manusia yang tidak siap dengan adanya teknologi yang baru (Siagian, 2012:2-3). Faktor ini berfungsi sebagai pendorong dalam rangka untuk peningkatan kinerja para karyawan dalam rangka mewujudkan tujuan 
organisasi. Kemampuan seorang pimpinan untuk memberikan dukungan terkait dalam upaya peningkatan kinerja karyawan sangat diperlukan, dimana salah satunya mengenai gaya kepemimpinan. Gaya kepemimpinan menunjukkan kemampuan individu untuk mempengaruhi, memotivasi, dan membuat orang lain mampu memberikan kontribusinya demi efektivitas dan keberhasilan organisasi (Gary Yukl, 2009:4). Kepemimpinan situasional pada dasarnya terbagi menjadi empat kriteria gaya kepemimpinan yaitu gaya kepemimpinan telling/directing, selling/ coaching, participating/ supporting dan delegating/observing,

PDAM Kota Probolinggo dalam memaksimalkan pelayanan kepada masyarakat dan peran kepemimpinan di perusahaan menjadi salah satu faktor penentu keberhasilan perusahaan dalam pengembangan aktivitas operasionaol perusahaan.Pimpinan masing-masing bagian yaitu memiliki sikap tegas dalam menjalankan aktivitas rutin yang harus dilakukan para pegawai. Selain itu pimpinan selalu menetapkan target kerja yang tinggi kepada karyawan sehingga karyawan mendapatkan tekanan untuk melaksanakan tugas atau pekerjaan yang ditetapkan oleh instansi.Kondisi tersebut menjadikan karyawan merasakan bahwa pekerjaan yang dibebankan kepada pegawai terlalu memberatkan sehingga pekerjaan tidak dapat diselesaikan sesuai dengan ketentuan yang ditetapkan. Apabila dikaitakan dengan tingkat kematangan karyawan menunjukkan bahwa selama ini karyawan belum memiliki kemampuan sesuai dengan bidang kerja yang harus diselesaikan. Kondisi ini terjadi karena selama ini pimpinan dalam menetapkan tugas kepada karyawan belum sepenuhnya mempertimbangkan kemampuan dan tingkat pendidikan yang dimiliki oleh karyawan.

Rumusan masalah yang diajukan dalam penelitian ini yaitu Bagaimana kematangan bawahan di bagian administrasi dan keuangan, bagian hubungan pelanggan, dan bagian teknik?, Bagaimana Perilakutugas dan perilaku hubungan kepala bagian administrasi dan keuangan, bagian hubungan pelanggan, dan bagian teknik?, Bagaimana gaya kepemimpinan yang diterapkan di bagian administrasi dan keuangan, bagian hubungan pelanggan, dan bagian teknik?, Apakah gaya kepemimpinan yang diterapkan di bagian administrasi dan keuangan, bagian hubungan pelanggan, dan bagian teknik sesuai dengan model Hersey dan Blanchard?

\section{TINJAUAN PUSTAKA}

Menurut Thoha (2004:256) berpendapat bahwa "kepemimpinan adalah kemampuan untuk membangkitkan semangat orang lain dan memiliki semangat total terhadap usaha mencapai tujuan organisasi. Menurut Mohyi (2005:161) yang dimaksud kepemimpinan adalah kegiatan mempengaruhi,mengorganisir, menggerakkan, mengarahkan atau mempengaruhi orang lain (bawahan) untuk melaksanakan sesuatu dalam rangka mencapai tujuan".

Dalam teori kepemimpinan situasional terdapat beberapa gaya kepemimpinan seperti yang disebutkan sebagai berikut. Pertama telling (Pemberitahu), gaya kepemimpinan yang paling tepat untuk kesiapan pengikut rendah. Ini menekankan perilaku tugas tinggi dan perilaku hubungan yang terbatas. Gaya kepemimpinan telling (kadangkadang disebut directing) adalah 
karakteristik gaya kepemimpinan dengan komunikasi satu arah. Kedua selling (penjual), Gaya ini paling tepat untuk kesiapan pengikut moderat. Ini menekankan pada jumlah tugas dan perilaku hubungan yang tinggi. Pada tahapan gaya kepemimpinan ini seorang pemimpin masih memberi arahan namun ia menggunakan komunikasi dua arah dan memberi dukungan secara emosional terhadap individu atau kelompok untuk memotivasinya.

Keempat participating, gaya ini paling tepat untuk kesiapan pengikut tinggi dengan motivasi moderat. Ini menekankan pada jumlah tinggi perilaku hubungan tetapi jumlah
Perilaku tugas rendah. Gaya kepemimpinan pada tahap ini mendorong individu atau kelompok untuk saling berbagi gagasan dan sekaligus memfasilitasi pekerjaan dengan semangat yang mereka tunjukkan".

Keempat yaitu delegating (pendelegasian), Gaya ini paling tepat untuk kesiapan pengikut tinggi. Ini menekankan pada kedua sisi yaitu tingginya perilaku kerja dan perilaku hubungan dimana gaya kepemimpinan pada tahap ini cenderung mengalihkan tanggung jawab atas proses pembuatan keputusan dan pelaksanaannya. Kerangka pikir dalam penelitian ini akan ditujukkan oleh Gambar 1.

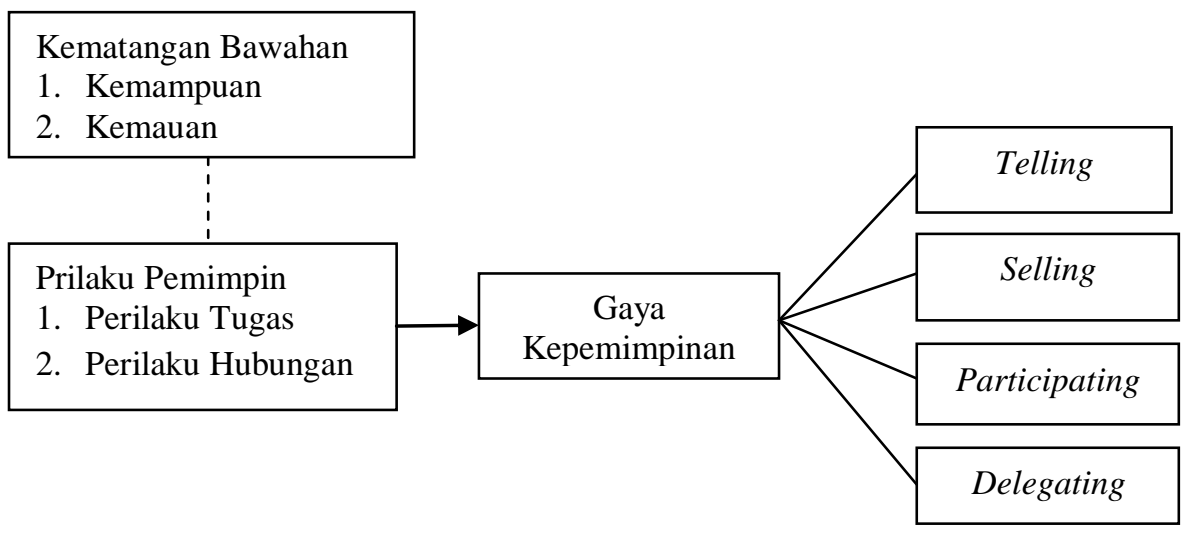

Gambar 1. Kerangka Pikir Penelitian

\section{METODE PENELITIAN}

Lokasi penelitian digunakan menjadi objek penelitin digunakan menjadi objek penelitian ini adalah pada PDAM Kota Probolinggo Jalan Hayam Wuruk No. 5. Jenis penelitian yang digunakan adalah penelitian survei. Populasi yang digunakan dalam penelitian ini adalah seluruh pegawai tetap yaitu sebanyak 59 pegawai yang terdapat di 3 bagian meliputi 20 Bagian Administrasi dan Keuangan,
23 Bagian Hubungan Pelanggan, dan 16 Bagian Teknik. Peneliti mengunakan teknik pengambilan sampel Total Sampling dimana teknik ini mengambil sampel dari seluruh jumlah populasi yaitu 59 pegawai. Teknik pengukuran variabel menggunakan skala likert, uji instrumen penelitian menggunakan uji validitas dan uji reliabilitas, metode analisis data menggunakan rentang skala. 
HASIL PENELITIAN DAN kuisioner yang telah diberikan PEMBAHASAN

kepada pegawai di PDAM Kota

Berdasarkan hasil penelitian yang dilakukan di PDAM Kota Probolinggo (Model Hersey dan Blanchard) maka dapat diketahui dari diskripsi jawaban responden atas Probolinggo sebagai dasar dalam melakukan analisis gaya kepemimpinan, dan secara lengkap diskripsi jawaban responden dapat diuraikan sebagai berikut :

Tabel 2. Kematangan Bawahan $\left(\mathrm{X}_{1}\right)$

\begin{tabular}{|c|c|c|c|c|c|c|}
\hline \multirow{2}{*}{ Item } & \multicolumn{4}{|c|}{ Jawaban Responden } & \multirow{2}{*}{$\begin{array}{c}\text { Skor Retang } \\
\text { Skala }\end{array}$} & \multirow{2}{*}{ Keterangan } \\
\hline & SS & $\mathrm{S}$ & TS & STS & & \\
\hline $\mathrm{X}_{1.1}$ & 13 & 3 & 4 & 0 & 69 & Sangat Tinggi \\
\hline $\mathrm{X}_{1.2}$ & 12 & 7 & 1 & 0 & 71 & Sangat Tinggi \\
\hline $\mathrm{X}_{1.3}$ & 10 & 6 & 4 & 0 & 66 & Sangat Tinggi \\
\hline $\mathrm{X}_{1.4}$ & 13 & 7 & 0 & 0 & 73 & Sangat Tinggi \\
\hline $\mathrm{X}_{1.5}$ & 12 & 6 & 2 & 0 & 70 & Sangat Tinggi \\
\hline $\mathrm{X}_{1.6}$ & 13 & 6 & 1 & 0 & 72 & Sangat Tinggi \\
\hline \multicolumn{5}{|c|}{ Rata-Rata } & 70,17 & Sangat Tinggi \\
\hline
\end{tabular}

Hasil perhitungan rata-rata rentang skala diperoleh angka sebesar 70,17 yang berarti bahwa kematangan bawahan Bagian Administrasi Keuangan termasuk ke dalam kategori sangat tinggi. Kategori sangat tinggi dapat diartikan bahwa karyawankaryawan yang ada pada Bagian Administrasi Keuangan memiliki kemampuan dalam bekerja dan kemauan dalam bekerja yang sangat tinggi.

Tabel 3. PerilakuTugas $\left(X_{2}\right)$

\begin{tabular}{|c|c|c|c|c|c|c|}
\hline \multirow{2}{*}{ Item } & \multicolumn{4}{|c|}{ Jawaban Responden } & \multirow{2}{*}{$\begin{array}{c}\text { Skor Retang } \\
\text { Skala }\end{array}$} & \multirow{2}{*}{ Keterangan } \\
\hline & SS & $\mathrm{S}$ & TS & STS & & \\
\hline $\mathrm{X}_{2.1}$ & 13 & 3 & 4 & 0 & 69 & Sangat Tinggi \\
\hline $\mathrm{X}_{22}$ & 11 & 7 & 2 & 0 & 69 & Sangat Tinggi \\
\hline $\mathrm{X}_{2.3}$ & 11 & 7 & 2 & 0 & 69 & Sangat Tinggi \\
\hline $\mathrm{X}_{2.4}$ & 15 & 4 & 1 & 0 & 74 & Sangat Tinggi \\
\hline $\mathrm{X}_{2.5}$ & 12 & 5 & 3 & 0 & 69 & Sangat Tinggi \\
\hline \multicolumn{5}{|c|}{ Rata-Rata } & 70 & Sangat Tinggi \\
\hline
\end{tabular}

Rata-rata rentang skala diperoleh angka sebesar 70 yang artinya bahwa Perilakutugas Bagian Administrasi dan Keuanganmasuk dalam kategori sangat tinggi. Hasil sangat tinggi dapat diartikan bahwa selama ini karyawan merasakan bahwa pemberian instruksi pimpinan dalam memberikan tugas kepada karyawan dan pemberian dorongan kerja pimpinan dalam proses penyelesaian pekerjaan masuk dalam kategori sangat tinggi. 
Tabel 4. Perilaku hubungan $\left(\mathrm{X}_{3}\right)$

\begin{tabular}{|c|c|c|c|c|c|c|}
\hline \multirow{2}{*}{ Item } & \multicolumn{4}{|c|}{ Jawaban Responden } & \multirow{2}{*}{$\begin{array}{c}\text { Skor Retang } \\
\text { Skala }\end{array}$} & \multirow{2}{*}{ Keterangan } \\
\hline & SS & $\mathrm{S}$ & TS & STS & & \\
\hline $\mathrm{X}_{3.1}$ & 13 & 6 & 1 & 0 & 72 & Sangat Tinggi \\
\hline $\mathrm{X}_{3.2}$ & 13 & 6 & 1 & 0 & 72 & Sangat Tinggi \\
\hline $\mathrm{X}_{3.3}$ & 15 & 4 & 1 & 0 & 74 & Sangat Tinggi \\
\hline $\mathrm{X}_{3.4}$ & 13 & 6 & 1 & 0 & 72 & Sangat Tinggi \\
\hline $\mathrm{X}_{3.5}$ & 15 & 2 & 3 & 0 & 72 & Sangat Tinggi \\
\hline \multicolumn{5}{|c|}{ Rata-Rata } & 72,4 & Sangat Tinggi \\
\hline
\end{tabular}

Hasil analisis rentang skala diperoleh angka sebesar 72,4 yang berarti bahwa perilaku hubungan Bagian Administrasi dan Keuangan masuk dalam kategori sangat tinggi. Perbandingan gaya kepemimpinan yang diterapkan oleh dinas PDAM Kota Probolinggo khususnya bagian adminsitrasi keuangan dan gaya kepemimpinan menurut Hersey dan Blanchard, dan hasil perbandingan tersebut dapat dilihat pada Tabel 5.

Tabel 5. Gaya Kepemimpinan Administrasi Keuangan

\begin{tabular}{|c|c|c|c|c|}
\hline \multirow[b]{2}{*}{ Keterangan } & \multirow[b]{2}{*}{ Hasil Analisis } & \multirow[b]{2}{*}{$\begin{array}{l}\text { Hersey dan } \\
\text { Blanchard }\end{array}$} & \multicolumn{2}{|c|}{ Gaya Kepemimpinan } \\
\hline & & & $\begin{array}{c}\text { Hasil analisis } \\
\text { yang diterapkan } \\
\text { perusahaan }\end{array}$ & $\begin{array}{c}\text { Hersey } \\
\text { dan } \\
\text { Blanchard }\end{array}$ \\
\hline Kematangan bawahan & Sangat Tinggi & Sangat Tinggi & & \\
\hline PerilakuTugas & Sangat Tinggi & Sangat Rendah & & \\
\hline Perilaku hubungan & Sangat Tinggi & Sangat Rendah & Telling & Delegating \\
\hline
\end{tabular}

Tabel 5. menunjukkan bahwa kematangan bawahan masuk kriteria sangat tinggi, Perilakutugas dan perilaku hubungan masuk dalam kriteria sangat tinggi. Hasil tersebut menunjukkan bahwa gaya kepemimpinan berdasarkan hasil analisis pada Bagian Administrasi dan Keuangan yaitu telling. Apabila ditinjau dari teori Harsey dan Blanchard maka untuk kematangan bawahan masuk kriteria sangat tinggi, Perilakutugas dan perilaku hubungan masuk kriteria sangat rendah, maka gaya kepemimpinan yang sesuai yaitu delegating.

Tabel 6. Kematangan Bawahan $\left(X_{1}\right)$

\begin{tabular}{|c|c|c|c|c|c|c|}
\hline \multirow{2}{*}{ Item } & \multicolumn{4}{|c|}{ Jawaban Responden } & \multirow{2}{*}{$\begin{array}{l}\text { Skor Retang } \\
\text { Skala }\end{array}$} & \multirow{2}{*}{ Keterangan } \\
\hline & SS & $\mathrm{S}$ & TS & STS & & \\
\hline $\mathrm{X}_{1.1}$ & 11 & 5 & 7 & 0 & 73 & Tinggi \\
\hline $\mathrm{X}_{1.2}$ & 11 & 9 & 3 & 0 & 77 & Sangat Tinggi \\
\hline $\mathrm{X}_{1.3}$ & 13 & 5 & 5 & 0 & 77 & Sangat Tinggi \\
\hline $\mathrm{X}_{1.4}$ & 15 & 7 & 1 & 0 & 83 & Sangat Tinggi \\
\hline $\mathrm{X}_{1.5}$ & 14 & 8 & 1 & 0 & 82 & Sangat Tinggi \\
\hline $\mathrm{X}_{1.6}$ & 15 & 7 & 1 & 0 & 83 & Sangat Tinggi \\
\hline \multicolumn{5}{|c|}{ Rata-Rata } & 79,17 & Sangat Tinggi \\
\hline
\end{tabular}


Hasil rata-rata rentang skala kematangan bawahan Bagian diperolehpada penelitian ini adalah Hubungan Pelanggan masuk dalam sebesar 79,17 yang berarti bahwa kategori sangat tinggi.

Tabel 7. PerilakuTugas $\left(\mathrm{X}_{2}\right)$

\begin{tabular}{|c|c|c|c|c|c|c|}
\hline \multirow{2}{*}{ Item } & \multicolumn{4}{|c|}{ Jawaban Responden } & \multirow{2}{*}{$\begin{array}{c}\text { Skor Retang } \\
\text { Skala }\end{array}$} & \multirow{2}{*}{ Keterangan } \\
\hline & SS & $S$ & TS & STS & & \\
\hline $\mathrm{X}_{2.1}$ & 12 & 10 & 1 & 0 & 80 & Sangat Tinggi \\
\hline $\mathrm{X}_{2.2}$ & 12 & 11 & 0 & 0 & 81 & Sangat Tinggi \\
\hline $\mathrm{X}_{2.3}$ & 17 & 5 & 1 & 0 & 85 & Sangat Tinggi \\
\hline $\mathrm{X}_{2.4}$ & 12 & 6 & 5 & 0 & 76 & Sangat Tinggi \\
\hline $\mathrm{X}_{2.5}$ & 13 & 9 & 1 & 0 & 81 & Sangat Tinggi \\
\hline \multicolumn{5}{|c|}{ Rata-Rata } & 80,6 & Sangat Tinggi \\
\hline
\end{tabular}

Rata-rata rentang skala diperoleh angka sebesar 80,6 yang berarti bahwa perilaku tugas Bagian Hubungan Pelanggan termasuk ke dalam kategori sangat tinggi. Hasil tersebut menunjukkan bahwa selama ini pemimpin memiliki dukungan dalam memberikan penjelasan tentang detail dari tugas- tugas, merupakan bentuk upaya pimpinan untuk proses penyelesaian pekerjaan, tingkat pengendalian atas pekerjaan, upaya pimpinan untuk melaksanakan tugas atau pekerjaan sesuai dengan ketentuan dan tingkat penetapan batas waktu, merupakan penetapan batas waktu penyelesaian pekerjaan yang diberikan oleh pimpinan.

Tabel 8 Perilaku hubungan $\left(\mathbf{X}_{3}\right)$

\begin{tabular}{|c|c|c|c|c|c|c|}
\hline \multirow[t]{2}{*}{ Item } & \multicolumn{4}{|c|}{ Jawaban Responden } & \multirow{2}{*}{$\begin{array}{c}\text { Skor Retang } \\
\text { Skala }\end{array}$} & \multirow[t]{2}{*}{ Keterangan } \\
\hline & SS & $\mathrm{S}$ & TS & STS & & \\
\hline $\mathrm{X}_{3.1}$ & 12 & 4 & 7 & 0 & 74 & Sangat Tinggi \\
\hline $\mathrm{X}_{3.2}$ & 11 & 9 & 3 & 0 & 77 & Sangat Tinggi \\
\hline $\mathrm{X}_{3.3}$ & 16 & 7 & 0 & 0 & 85 & Sangat Tinggi \\
\hline $\mathrm{X}_{3.4}$ & 16 & 6 & 1 & 0 & 84 & Sangat Tinggi \\
\hline $\mathrm{X}_{3.5}$ & 16 & 6 & 1 & 0 & 84 & Sangat Tinggi \\
\hline \multicolumn{5}{|c|}{ Rata-Rata } & 80,8 & Sangat Tinggi \\
\hline
\end{tabular}

Hasil perhitungan rata-rata rentang skala diperoleh angka sebesar 80,8 yang berarti bahwa perilaku hubungan Bagian Hubungan Pelanggan termasuk ke dalam kategori sangat tinggi. Dari hasil analisis maka dapat diketahui perbandingan gaya kepemimpinan yang diterapkan khususnya bagian hubungan pelanggan dan gaya kepemimpinan menurut Hersey dan Blanchard. Hasil perbandingan tersebut akan dipaparkan secara rinci pada Tabel 9. 
Tabel 9. Gaya Kepemimpinan Hubungan Pelanggan

\begin{tabular}{ccccc}
\hline Keterangan & Hasil Analisis & $\begin{array}{c}\text { Hersey dan } \\
\text { Blanchard }\end{array}$ & $\begin{array}{c}\text { Hasil analisis } \\
\text { yang diterapkan } \\
\text { perusahaan }\end{array}$ & $\begin{array}{c}\text { Hersey dan } \\
\text { Blanchard }\end{array}$ \\
\hline $\begin{array}{c}\text { Kematangan } \\
\text { bawahan }\end{array}$ & Sangat Tinggi & Sangat Tinggi & Telling & Delegating \\
$\begin{array}{c}\text { PerilakuTugas } \\
\text { Perilaku hubungan }\end{array}$ & $\begin{array}{c}\text { Sangat Tinggi } \\
\text { Sangat Tinggi }\end{array}$ & $\begin{array}{c}\text { Sangat Rendah } \\
\text { Sangat Rendah }\end{array}$ & & \\
\hline
\end{tabular}

Untuk hasil analisis rentang skala pada bagian Hubungan Pelanggan dapat diketahui bahwa kematangan bawahan masuk kriteria sangat tinggi. Perilaku tugas dan perilaku hubungan masuk dalam kriteria sangat tinggi. Hasil tersebut menunjukkan bahwa gaya kepemimpinan yang tepat untuk bagian Hubungan Pelanggan yaitu telling. Apabila ditinjau dari teori Harsey dan Blanchard maka untuk kematangan bawahan masuk kriteria sangat tinggi, Perilaku tugas dan perilaku hubungan masuk kriteria sangat rendah, maka gaya kepemimpinan yang sesuai yaitu delegating.

Tabel 10. Kematangan Bawahan $\left(X_{1}\right)$

\begin{tabular}{|c|c|c|c|c|c|c|}
\hline \multirow{2}{*}{ Item } & \multicolumn{4}{|c|}{ Jawaban Responden } & \multirow{2}{*}{$\begin{array}{c}\text { Skor Retang } \\
\text { Skala }\end{array}$} & \multirow{2}{*}{ Keterangan } \\
\hline & SS & $\mathrm{S}$ & $\mathrm{TS}$ & STS & & \\
\hline $\mathrm{X}_{1.1}$ & 6 & 4 & 6 & 0 & 48 & Tinggi \\
\hline $\mathrm{X}_{1.2}$ & 8 & 5 & 3 & 0 & 53 & Sangat Tinggi \\
\hline $\mathrm{X}_{1.3}$ & 9 & 6 & 1 & 0 & 56 & Sangat Tinggi \\
\hline $\mathrm{X}_{1.4}$ & 10 & 4 & 2 & 0 & 56 & Sangat Tinggi \\
\hline $\mathrm{X}_{1.5}$ & 10 & 4 & 2 & 0 & 56 & Sangat Tinggi \\
\hline $\mathrm{X}_{1.6}$ & 6 & $\begin{array}{c}6 \\
a-1\end{array}$ & 4 & 0 & $\begin{array}{c}50 \\
51,17\end{array}$ & $\begin{array}{l}\text { Tinggi } \\
\text { Tinggi }\end{array}$ \\
\hline
\end{tabular}

Berdasarkan hasil perhitungan rata-rata rentang skala diperoleh angka sebesar 51,17 yang berarti bahwa kematangan bawahan masuk dalam kategori tinggi.
Kategori sangat tinggi dapat diartikan bahwa karyawan bagian teknik memiliki kemampuan dalam bekerja dan kemauan dalam bekerja yang tinggi

Tabel 11. PerilakuTugas $\left(X_{2}\right)$

\begin{tabular}{|c|c|c|c|c|c|c|}
\hline \multirow{2}{*}{ Item } & \multicolumn{4}{|c|}{ Jawaban Responden } & \multirow{2}{*}{$\begin{array}{c}\text { Skor Retang } \\
\text { Skala }\end{array}$} & \multirow{2}{*}{ Keterangan } \\
\hline & SS & $S$ & TS & STS & & \\
\hline $\mathrm{X}_{2.1}$ & 8 & 4 & 4 & 0 & 52 & Sangat Tinggi \\
\hline $\mathrm{X}_{2.2}$ & 12 & 4 & 0 & 0 & 60 & Sangat Tinggi \\
\hline $\mathrm{X}_{2.3}$ & 12 & 3 & 1 & 0 & 59 & Sangat Tinggi \\
\hline $\mathrm{X}_{2.4}$ & 11 & 5 & 0 & 0 & 59 & Sangat Tinggi \\
\hline $\mathrm{X}_{2.5}$ & 11 & 5 & 0 & 0 & 59 & Sangat Tinggi \\
\hline \multicolumn{5}{|c|}{ Rata-rata } & 57,8 & Sangat Tinggi \\
\hline
\end{tabular}


Berdasarkan hasil perhitungan rata-rata rentang skala diperoleh angka sebesar 57,8 yang berarti bahwa perilaku tugas Bagian Teknik masuk dalam kategori sangat tinggi. Hasil sangat tinggi dapat diartikan bahwa selama ini karyawan telah merasakan bahwa pemberian instruksi dari pimpinan ketika memberikan tugas- tugas kepada karyawan serta pemberian dorongan atau motivasi kerja dari pimpinan dalam proses penyelesaian pekerjaan masuk dalam kategori sangat tinggi.

Tabel 12. Perilaku Hubungan $\left(X_{3}\right)$

\begin{tabular}{|c|c|c|c|c|c|c|}
\hline \multirow{2}{*}{ Item } & \multicolumn{4}{|c|}{ Jawaban Responden } & \multirow{2}{*}{$\begin{array}{c}\text { Skor Retang } \\
\text { Skala }\end{array}$} & \multirow{2}{*}{ Keterangan } \\
\hline & SS & $\mathrm{S}$ & TS & STS & & \\
\hline $\mathrm{X}_{3.1}$ & 11 & 5 & 0 & 0 & 59 & Sangat Tinggi \\
\hline $\mathrm{X}_{3.2}$ & 9 & 5 & 2 & 0 & 55 & Sangat Tinggi \\
\hline $\mathrm{X}_{3.3}$ & 8 & 4 & 4 & 0 & 52 & Sangat Tinggi \\
\hline $\mathrm{X}_{3.4}$ & 10 & 4 & 2 & 0 & 56 & Sangat Tinggi \\
\hline $\mathrm{X}_{3.5}$ & 12 & 4 & 0 & 0 & 60 & Sangat Tinggi \\
\hline \multicolumn{5}{|c|}{ Rata-Rata } & 56,4 & Sangat Tinggi \\
\hline
\end{tabular}

Berdasarkan hasil perhitungan ratarata rentang skala diperoleh angka sebesar 56,4 yang berarti bahwa perilaku hubungan Bagian Teknik masuk dalam kategori sangat tinggi. Hasil perbedaangaya kepemimpinanyang diterapkan diperusahaan dengan gaya kepemimpinan menurut Hersey dan Blanchard pada bagian teknik dapat disajikan pada Tabel 13.

Tabel 13. Gaya Kepemimpinan Bagian Teknik

\begin{tabular}{ccccc}
\hline & & & \multicolumn{2}{c}{ Gaya Kepemimpinan } \\
\cline { 4 - 5 } Keterangan & Hasil Analisis & $\begin{array}{c}\text { Hersey dan } \\
\text { Blanchard }\end{array}$ & $\begin{array}{c}\text { Hasil analisis } \\
\text { yang diterapkan } \\
\text { perusahaan }\end{array}$ & $\begin{array}{c}\text { Hersey dan } \\
\text { Blanchard }\end{array}$ \\
\hline $\begin{array}{c}\text { Kematangan bawahan } \\
\text { PerilakuTugas }\end{array}$ & $\begin{array}{c}\text { Tinggi } \\
\text { Sangat Tinggi }\end{array}$ & $\begin{array}{c}\text { Tinggi } \\
\text { Rendah }\end{array}$ & & \\
Perilaku hubungan & Sangat Tinggi & Rendah & Telling & Participating \\
\hline
\end{tabular}

Untuk hasil analisis rentang skala pada Bagian Teknik dapat diketahui bahwa kematangan bawahan masuk kriteria tinggi, Perilaku tugas dan perilaku hubungan masuk dalam kriteria sangat tinggi. Hasil tersebut menunjukkan bahwa gaya kepemimpinan berdasarkan hasil analisis pada Bagian Teknik yaitu telling. Apabila ditinjau dari teori Harsey dan Blanchard untuk kematangan bawahan masuk kriteria tinggi, Perilaku tugas dan perilaku hubungan masuk kriteria rendah, maka gaya kepemimpinan yang sesuai yaitu participating.

\section{KESIMPULAN}

Hasil analisis kematangan bawahan di bagian administrasi dan keuangan masuk kategori sangat tinggi, di bagian hubungan pelanggan masuk kategori sangat tinggi dan di bagian teknik masuk dalam kategori tinggi. Hasil analisis perilaku tugas kepala bagian dapat diketahui di bagian administrasi keuangan masuk kategori sangat tinggi, di bagian hubungan pelanggan masuk 
kategori sangat tinggi dan di bagian teknik masuk dalam kategori sangat tinggi. Sedangkan untuk perilaku hubungan di bagian administrasi dan keuangan masuk kategori sangat tinggi, di bagian hubungan pelanggan masuk kategori sangat tinggi dan di bagian teknik masuk dalam kategori sangat tinggi.

Hasil analisis gaya kepemimpinan yang diterapkan oleh kepala bagian adalah sebagai berikut: di bagian administrasi dan keuangan menerapkan gaya kepemimpinan telling, di bagian hubungan pelanggan menerapkan gaya kepemimpinan telling dan di bagian teknik menerapkan gaya kepemimpinan telling.

Gaya kepemimpinan yang diterapkan pada kepala bagian menurut model Hersey dan Blanchard di bagian administrasi dan keuangan yaitu delegating, di bagian hubungan pelanggan yaitu delegating dan bagian teknik yaitu participating. Gaya kepemimpinan yang diterapkan di masing-masing bagian tidak sesuai dengan gaya kepemimpinan menurut model Hersey dan Blanchard.

\section{DAFTAR PUSTAKA}

Ana Elok Imtihanah, 2009, Analisis Gaya Kepemimpinan Dalam Meningkatkan Kinerja Pegawai Pada Fakultas Ekonomi Universitas Islam Negeri Maulana Malik Ibrahim Malang, Skripsi Universitas Islam Negeri Maulana Malik Ibrahim Malang

Arifin, Amirullah, Fauziah, 2005, Perilaku Organisasi, Edisi 1, Penerbit Bayumedia, Malang.

As'ad, Muhammad. 2004. Psikologi Industri : seri Ilmu Sumber Daya Manusia. Edisi keempat,
Yogyakarta : Gajah Mada University Press.

Hasibuan, Malayu S.P, 2003, Manajemen Sumber Daya Manusia, Edisi Revisi, Bumi Aksara, Jakarta.

Jatmiko, 2013, Pemimpin dan Kepemimpinan Organisasi, Fakultas Ekonomi Universitas Esa Unggu

Kreitner, Robert dan Kinicki, Angelo. 2005. Perilaku Organisasi, buku 1 dan 2, Jakarta : Salemba Empat.

Luthans, 2006, Manajemen

Personalia Dan Sumber Daya

Manusia, Edisi 2, Cetakan

Ketujuh, BPFE, Yogyakarta.

Mangkunegara, Anwar Prabu, 2006, Manajemen Sumber Daya Manusia Perusahaan, Cetakan Kedua, PT. Remaja Rosdakarya Offset, Bandung.

Mohyi, Ahmad, 2005, Teori dan Perilaku Organisasi, Malang: CV. Cahaya Press.

Septyawan, 2015, Analisis Gaya Kepemimpinan Pada Pengadilan Negeri Situbondo, Skripsi Universitas Muhammadiyah Malang.

Siagian, P. Sondang, 2012, Sistem Informasi Manajemen. Jakarta: Bumi Aksara.

Sugiyono. 2006. Metode Penelitian Kuantitatif Kualitatif dan $R \& D$. Alfabeta, Bandung.

Thoha, Miftah, 2004, Perilaku Organisasi, Konsep Dasar dan Aplikasinya, Rajawali Jakarta.

Yukl, Gary A, 2009. Managerial Leadership: A Review of Theory and Research, Journal of Management, Vol 15, No.2, 251289 